\title{
FLOODS IN CUYAMA VALLEY, CALIFORNIA, FEBRUARY 1998
} \section{INTRODUCTION}

Flooding in southern California in recent years has been attributed to El Niño, a climate condition based on sea surface temperatures of the equatorial Pacific Ocean and on trade wind velocities. During El Niño conditions, trade winds diminish, and upwelling of colder water in the ocean is inhibited along the Pacific Coast of the United States. Precipitation is enhanced by increased evaporation from the warmer surface water. The result is an increase in the number and intensity of storms (Harmon, 1999). The storms that occurred in the Cuyama River Basin (fig. 1) in January and February 1998 were influenced by a very strong El Niño condition.

On February 23, 1998, severe flooding throughout the Cuyama River Basin resulted in damage to agricultural land and roads; a record flood peak of 26,200 cubic feet per second $\left(\mathrm{ft}^{3} / \mathrm{s}\right)$ occurred at 2330 hours at the U.S. Geological Survey streamgaging station on the Cuyama River below Buckhorn Canyon, near Santa Maria (11136800). In response, the U.S. Geological Survey, in cooperation with the Santa Barabara County Flood Control District and Water Agency, undertook a study to assess the magnitude and frequency (exceedence probability) of the flood, the distribution of tributary flood peaks in the basin, and factors that contributed to flooding. Continuous flow data has been collected at the Cuyama River below Buckhorn Canyon since October 1959; the previous record peak, $17,800 \mathrm{ft}^{3} / \mathrm{s}$, occurred on February 25, 1969 (U.S. Geological Survey, 1969).

Precipitation data for the February 22-24 storm (table 1) were provided by the Santa Barbara County Flood Control District and the Ventura County Flood Control District. Although much of the rainfall data are from automated gages operated by the counties for flood warning (not for recording official rainfall), these data are useful for analyzing the timing and intensity of rainfall and for obtaining precipitation estimates for areas not covered by more highly calibrated gages.

To document the distribution of flood peaks in the basin, 15 sites on the Cuyama River and its tributaries were selected for indirect measurements of peak discharge (fig. 2). Standard engineering surveying methods were used to measure the width, depth, slope, and elevation of peak flow for selected channel reaches. These data were then used to compute peak discharge using various indirect computational methods. The computed peak discharge for each peak flow measurement site is listed in table 2. The estimated peak discharge for station 11136500, Cuyama River near Ventucopa, was based on the surveyed peak-stage high-water mark and the stage/discharge rating curve for prior years. The estimates for the Post Canyon and the Moralis Canyon sites were based on field-measured cross sectional area and estimated peak velocity.

Stream-gaging station 11136800 , Cuyama River below Buckhorn Canyon, is located on the downstream side of the bridge over the Cuyama River on State Highway 166, 1.5 miles downstream from Buckhorn Canyon and 13 miles northeast of Santa Maria. The drainage area of the Cuyama River Basin upstream from this gaging station is 886 square miles. The river valley trends northwest to southeast and drains the east side of the Sierra Madre Range, the north side of the Pine Mountains at the southern end of the basin near the headwaters of the Cuyama River, and the western face of Mt. Pinos. The Cuyama River flows into Twitchell Reservoir downstream from gaging station 11136800, and

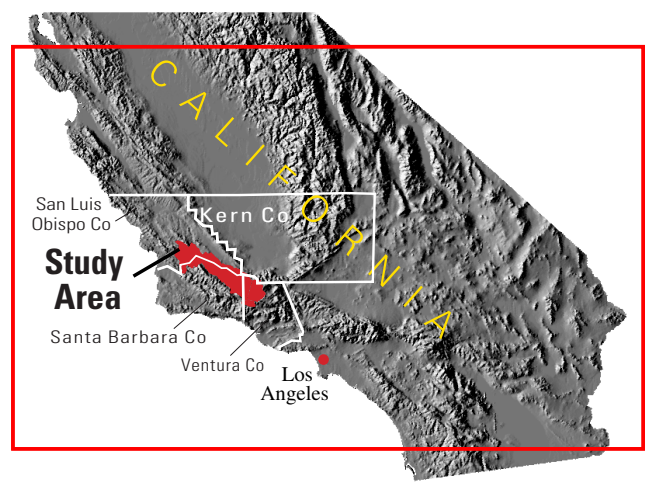

Figure 1. Location of study area.

then joins with the Sisquoc River to form the Santa Maria River, which flows to the west to the Pacific Ocean near Guadalupe.

\section{PRECIPITATION}

A warm tropical storm, which produced no snow in the higher elevations of the headwaters of the Cuyama River, moved across the Cuyama Basin February 22-24, 1998. This storm followed a series of intense storms in late January and early February that had resulted in high antecedent soil moisture conditions in the basin. Precipitation totals for the period 0800 hours on February 22 to 0800 hours on February 24 ranged from 1.37 inches at the precipitation gage at Apache Canyon on the east side of the basin to 8.62 inches at the gage at Matilija Canyon on the coastal side of the ridge, just southwest of the headwaters of the Cuyama River. The initial rainstorm moved in from the Pacific Ocean from the southwest. Precipitation was intensified by the air-cooling effects of the orographic lift as the rainstorm moved over the east-west trending mountain range at the headwaters of the Cuyama River. The type of the February 22-24 storm compounded its effects. In meteorological terms, this storm was an "open 


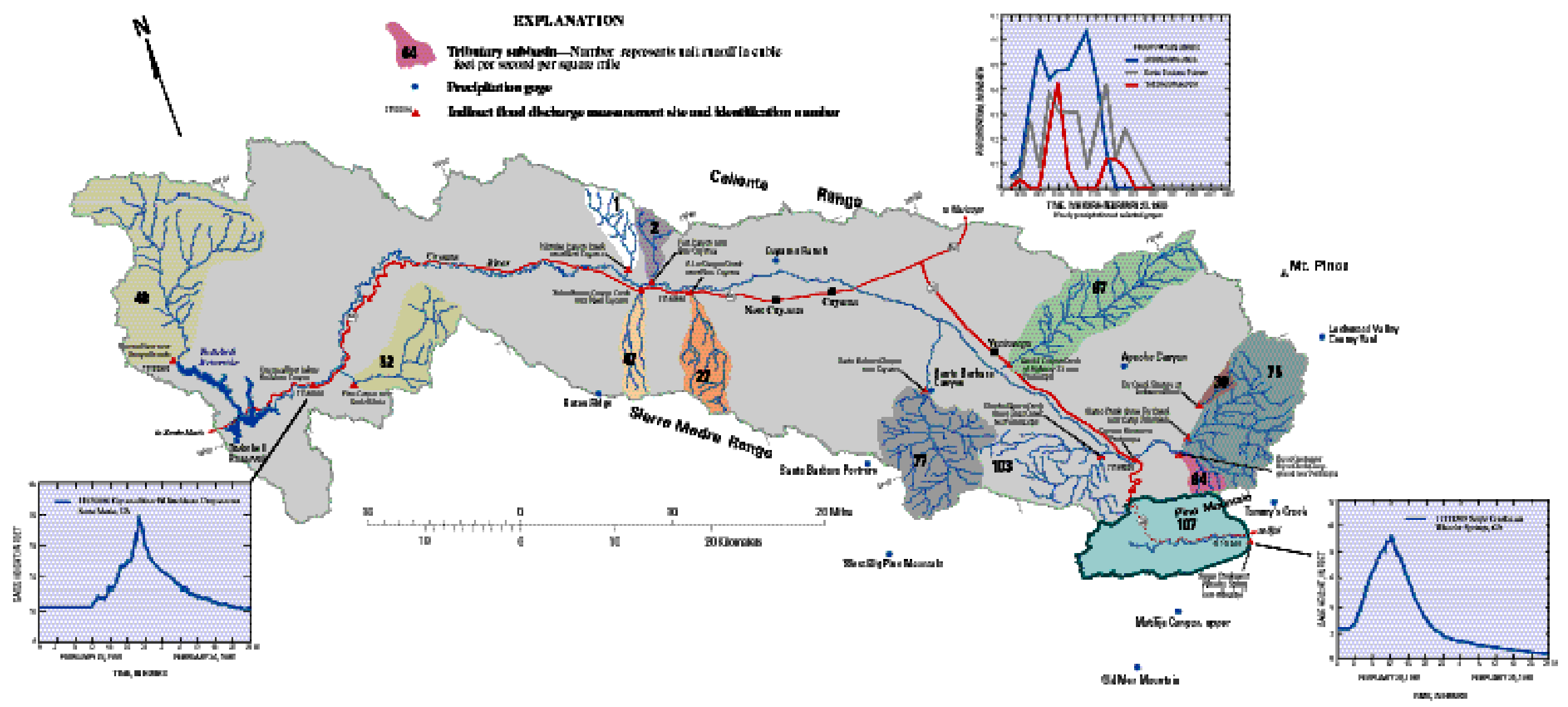


Table 1. Precipitation at gages in or near the Cuyama River Basin, California, February 22-24, 1998

[Elevations are in feet above sea level. SBCFCD, Santa Barbara County Flood Control District; VCFCD, Ventura County Flood Control District]

\begin{tabular}{|c|c|c|c|c|c|c|}
\hline \multirow{2}{*}{ Latitude } & \multirow{2}{*}{ Longitude } & \multirow{2}{*}{ Precipitation gage } & \multicolumn{4}{|c|}{ Precipitation, in inches } \\
\hline & & & Feb. 22 & Feb. 23 & Feb. 24 & Total \\
\hline $34^{\circ} 58^{\prime} 57^{\prime \prime}$ & $119^{\circ} 40^{\prime} 05^{\prime \prime}$ & $\begin{array}{l}\text { Cuyama Ranch (Russell Ranch) (SBCFCD, gage CUY221) } \\
\text { Elevation: 2,130 feet }\end{array}$ & 0.45 & 0.54 & 0.39 & 1.38 \\
\hline $34^{\circ} 55^{\prime} 11^{\prime \prime}$ & $119^{\circ} 55^{\prime} 02^{\prime \prime}$ & $\begin{array}{l}\text { Bates Ridge (SBCFCD, gage 456) } \\
\text { Elevation: 5,120 feet }\end{array}$ & 1.34 & 1.02 & .67 & 3.03 \\
\hline $34^{\circ} 49^{\prime} 00^{\prime \prime}$ & $119^{\circ} 33^{\prime} 40^{\prime \prime}$ & Santa Barbara Canyon (SBCFCD, gage 550) & .45 & 1.00 & .75 & 2.20 \\
\hline $34^{\circ} 46^{\prime} 27^{\prime \prime}$ & $119^{\circ} 28^{\prime} 53^{\prime \prime}$ & $\begin{array}{l}\text { Santa Barbara Portrero (SBCFCD, gage 238) } \\
\text { Elevation: } 4,970 \text { feet }\end{array}$ & .63 & .89 & 2.38 & 3.90 \\
\hline $34^{\circ} 46^{\prime} 27^{\prime \prime}$ & $119^{\circ} 19^{\prime} 50^{\prime \prime}$ & $\begin{array}{l}\text { Apache Canyon (SBCFCD, gage 523) } \\
\text { Elevation: } 4,410 \text { feet }\end{array}$ & .31 & .59 & .47 & 1.37 \\
\hline $34^{\circ} 44^{\prime} 02^{\prime \prime}$ & $119^{\circ} 06^{\prime} 00^{\prime \prime}$ & $\begin{array}{l}\text { Lockwood Valley County Yard (VCFCD, gage } 0170) \\
\text { Elevation: 5,150 feet }\end{array}$ & .91 & 1.30 & 1.22 & 3.43 \\
\hline $34^{\circ} 41^{\prime} 26^{\prime \prime}$ & $119^{\circ} 39^{\prime} 52^{\prime \prime}$ & $\begin{array}{l}\text { West Big Pine Mountain (SBCFCD, gage 450) } \\
\text { Elevation: } 6,360 \text { feet }\end{array}$ & 3.50 & 2.91 & 1.26 & 7.67 \\
\hline $34^{\circ} 36^{\prime} 14^{\prime \prime}$ & $119^{\circ} 13^{\prime} 17^{\prime \prime}$ & $\begin{array}{l}\text { Tommy's Creek (VCFCD, gage 0040) } \\
\text { Elevation: 5,250 feet }\end{array}$ & 1.06 & 2.64 & 2.56 & 6.26 \\
\hline $34^{\circ} 32^{\prime} 28^{\prime \prime}$ & $119^{\circ} 22^{\prime} 16^{\prime \prime}$ & $\begin{array}{l}\text { Matilija Canyon (Upper) (VCFCD, gage 0029) } \\
\text { Elevation: 4,400 feet }\end{array}$ & 1.81 & 3.35 & 3.46 & 8.62 \\
\hline $34^{\circ} 30^{\prime} 17^{\prime \prime}$ & $119^{\circ} 26^{\prime} 18^{\prime \prime}$ & $\begin{array}{l}\text { Old Man Mountain (VCFCD, gage 613) } \\
\text { Elevation: } 4,370 \text { feet }\end{array}$ & 1.22 & 3.07 & 1.22 & 5.51 \\
\hline
\end{tabular}

Table 2. Flood-peak data for selected sites in the Cuyama River Basin, California, February 23, 1998

[USGS, U.S. Geological Survey. USGS site identification No.: Unique number for each site based on the latitude and longitude of the site. First six digits are latitude, next seven digits are longitude, and final two digits are a sequence number to uniquely identify each $\mathrm{site}^{\mathrm{ft}} \mathrm{ft}^{3} / \mathrm{s}$, cubic foot per second; $\mathrm{mi}^{2}$, square $\mathrm{mile} ;\left(\mathrm{ft}^{3} / \mathrm{s}\right) / \mathrm{mi}^{2}$, cubic foot per second per square mile]

\begin{tabular}{|c|c|c|c|c|}
\hline $\begin{array}{c}\text { USGS site } \\
\text { identification No. }\end{array}$ & Site name & $\begin{array}{c}\text { Peak } \\
\text { discharge } \\
\left(\mathrm{ft}^{3} / \mathrm{s}\right) \\
\end{array}$ & $\begin{array}{c}\text { Drainage } \\
\text { area } \\
\left(\mathrm{mi}^{2}\right) \\
\end{array}$ & $\begin{array}{c}\text { Unit } \\
\text { runoff } \\
{\left[\left(\mathrm{ft}^{3} / \mathrm{s}\right) / \mathrm{mi}^{2}\right)}\end{array}$ \\
\hline 350440120221501 & Huasna River near Arroyo Grande (discontinued gaging station, 11137900) & 4,900 & 103 & 47.6 \\
\hline 340110120133901 & Cuyama River below Buckhorn Canyon (gaging station, 11136800) & 26,200 & 886 & 29.6 \\
\hline 350056120110201 & Pine Canyon Creek above Buckhorn Canyon & 1,100 & 21.2 & 51.9 \\
\hline 350121119590501 & Morales Canyon Creek near New Cuyama & ${ }^{1} 15$ & 11.1 & 1.4 \\
\hline 350002119494501 & Schoolhouse Canyon Creek near New Cuyama & 495 & 10.6 & 46.7 \\
\hline 350015119485201 & Post Canyon near New Cuyama & ${ }^{1} 10$ & 5.1 & 2.0 \\
\hline 345855119463201 & Aliso Canyon Creek near New Cuyama (discontinued gaging station, 11136650) & 430 & 16.1 & 26.7 \\
\hline 344906119333101 & Santa Barbara Canyon near Cuyama & 3,100 & 40.3 & 76.9 \\
\hline 344852119272101 & Quatal Canyon Creek at Highway 33 near Ventucopa & 2,770 & 41.4 & 66.9 \\
\hline 344208119233201 & Rancho Nuevo Creek above Tinta Canyon near Ventucopa & 2,730 & 26.6 & 103 \\
\hline 344120119212501 & Cuyama River near Ventucopa (discontinued gaging station, 11136500) & ${ }^{1} 11,000$ & 89.9 & 122 \\
\hline 344042119182201 & Reyes Creek near Reyes Creek Campground near Ventucopa & 267 & 4.2 & 63.6 \\
\hline 344126119172401 & Alamo Creek above Dry Creek near Camp Scheideck & 4,230 & 56.4 & 75.0 \\
\hline 344256119155201 & Dry Creek Tributary at Lockwood Road & 58 & 1.9 & 30.5 \\
\hline 343440119152501 & Sespe Creek near Wheeler Springs (discontinued gaging station, 11111500$)^{2}$ & 5,290 & 49.5 & 107 \\
\hline
\end{tabular}

${ }^{1}$ Estimated.

${ }^{2}$ Adjacent basin, nontributary. 
wave" type weather system. In such systems, precipitation forms in a wide band ahead of the warm front and in a narrow band behind the cold front (Dennis R. Gibbs, Santa Barbara Flood Control District and Water Agency, written commun., 1999). The greatest amount of rain in the basin fell with the passage of the warm front. Moderate intensity rain fell during a sustained period throughout the morning of February 23; it ranged from 0.40 inch per hour at the Santa Barbara Portrero gage to more than 0.65 inch per hour at the Old Man Mountain gage (Santa Barbara and Ventura County data). Near the headwaters of the Cuyama River, where the highest rain totals were recorded, the most intense period of rain had ceased by 1030 hours. In the middle of the basin, heavy rain continued until 1400 hours at the Santa Barbara Portrero gage as the cold front passed through. As the flood peak from the headwaters moved down the basin, intense precipitation continued in the middle of the basin which produced extreme runoff from the tributaries, amplifying the flood peak in the river and producing a "double peak" where each tributary entered the main river channel.

\section{FLOOD MAGNITUDE}

The magnitude of the peak flows from channels tributary to the Cuyama River correlates well with the magnitude of precipitation, and the distribution of runoff from the tributary basins compares well with the precipitation totals. Unit runoff values, in cubic feet per second per square mile $\left[\left(\mathrm{ft}^{3} / \mathrm{s}\right) / \mathrm{mi}^{2}\right]$, are listed in table 2 and shown on figure 2 . Runoff in the headwaters area exceeded $100\left(\mathrm{ft}^{3} / \mathrm{s}\right) / \mathrm{mi}^{2}$. Near the middle part of the upper basin and on the eastern side of the headwaters, runoff was about $70\left(\mathrm{ft}^{3} / \mathrm{s}\right) / \mathrm{mi}^{2}$. In the lower or northern part of the basin, runoff ranged between 25 and $50\left(\mathrm{ft}^{3} / \mathrm{s}\right) / \mathrm{mi}^{2}$, depending on the topographic orientation of the basins relative to the storm direction. Runoff contribution from the Caliente Range on the northeast boundary of the middle basin was negligible, ranging from 1 to $2\left(\mathrm{ft}^{3} / \mathrm{s}\right) / \mathrm{mi}^{2}$.

Peak flow at Sespe Creek near Wheeler Springs stream-gaging station (11111500) occurred at 1215 hours on February 23 owing to the heavy precipitation associated with the passage of the warm front. This gaging station is in the upper part of the Sespe Creek drainage basin, immediately over the ridge to the south of and adjacent to the Cuyama River headwaters. Peak flow at the gaging station was used to indicate the time of the peak flow in the upper part of the Cuyama River Basin (fig. 2). In the lower part of the basin, the peak flow at the gaging station on the Cuyama River below Buckhorn Canyon (11136800) (fig. 2) occurred about 10 hours later, at 2230 hours. As the peak flow from the upper part of the basin moved downstream, the tributary channels in the middle and lower parts of the basin were still peaking or had just peaked owing to a second wave of precipitation associated with the passage of the cold front. The tributary inflows in the middle and lower part of the basin added to the total discharge in the river as it reached the lower part of the basin. The timing of the peak flows from the tributary basins in the middle part of the Cuyama River Basin was a major factor in the magnitude of the flood peak as it reached the lower part of the basin about 10 hours after the peak occurred in the upper part of the basin.

\section{FLOOD FREQUENCY}

The exceedence probability of the February 23 flood peak at gage 11136800 , calculated using 41 years of streamflow records, was 0.04 , or equivalent to a 25 -year flood. This exceedence probability compares well with the 24-hour precipitation frequency for most of the basin (Miller, 1973), which indicates that the storm of February 23 was a 25-year storm.

\section{Contributing factors}

The factors contributing to the magnitude and frequency of this flood are as follows:
- High antecedent soil-moisture conditions, which were caused by the earlier storms in late January through early February.

- The warm, tropical source of the moisture feeding the February 2224 storm. This storm produced no snow in the higher elevations of the drainage basin that resulted in high runoff.

- The timing of the precipitation. Sustained heavy rain fell in the upper part of the basin with passage of the warm front, followed by continued moderate rain in the middle part of the basin with passage of the cold front.

The runoff from tributary basins in the middle part of the basin had an additive effect on the flood peak as it moved downstream from the headwaters.

- The topographic orientation of the mountains surrounding the Cuyama River Basin. The mountains, which are nearly perpendicular to the direction of the flow of moisture associated with the warm front, caused extreme rainfall in the headwaters because of the rapid cooling of the moist air as it was lifted over the mountains.

\section{REFERENCES CITED}

U.S. Geological Survey, 1969, Water Resources Data, California: Part 1. Surface Water Records: Volume 1. Colorado River Basin, Southern Great Basin, and Pacific Slope Basins excluding Central Valley: U.S. Geological Survey Water Data Report, 500 p.

Harmon, J.G., 1999, Floods in Northern California, January 1997: U.S. Geological Survey Fact Sheet FS-073-99, 6 p.

Miller, J.F., Frederick, R.H., and Tracey, R.J., 1973 [1974], Precipitation-frequency atlas of the Western United States: Volume 11--California: U.S. Department of Commerce, National Oceanic and Atmospheric Administration Atlas 2, 71 p.

\section{For additional information on this report contact the author:}

James C. Bowers

13581 John Glenn Road

Apple Valley, California 92307

(760) 247-1401

e-mail: jcbowers@usgs.gov 